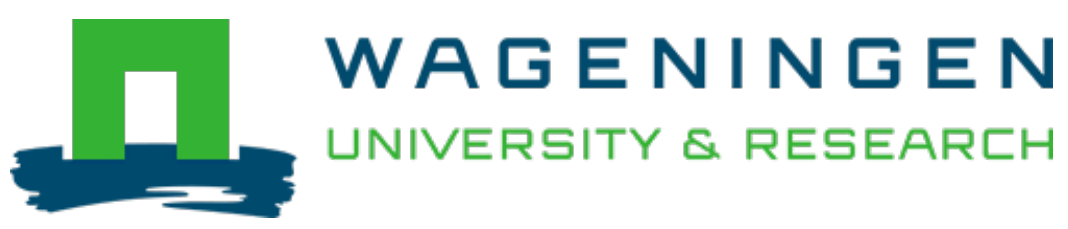

\title{
Mechanisms of increased linamarin degradation during solid-substrate fermentation of cassava
}

World Journal of Microbiology and Biotechnology

Essers, A.J.A.; Bennik, M.H.J.; Nout, M.J.R.

https://doi.org/10.1007/BF00367096

This publication is made publicly available in the institutional repository of Wageningen University and Research, under the terms of article $25 \mathrm{fa}$ of the Dutch Copyright Act, also known as the Amendment Taverne. This has been done with explicit consent by the author.

Article 25 fa states that the author of a short scientific work funded either wholly or partially by Dutch public funds is entitled to make that work publicly available for no consideration following a reasonable period of time after the work was first published, provided that clear reference is made to the source of the first publication of the work.

This publication is distributed under The Association of Universities in the Netherlands (VSNU) 'Article $25 \mathrm{fa}$ implementation' project. In this project research outputs of researchers employed by Dutch Universities that comply with the legal requirements of Article $25 \mathrm{fa}$ of the Dutch Copyright Act are distributed online and free of cost or other barriers in institutional repositories. Research outputs are distributed six months after their first online publication in the original published version and with proper attribution to the source of the original publication.

You are permitted to download and use the publication for personal purposes. All rights remain with the author(s) and / or copyright owner(s) of this work. Any use of the publication or parts of it other than authorised under article $25 \mathrm{fa}$ of the Dutch Copyright act is prohibited. Wageningen University \& Research and the author(s) of this publication shall not be held responsible or liable for any damages resulting from your (re)use of this publication.

For questions regarding the public availability of this publication please contact openscience.library@wur.nl 


\title{
Mechanisms of increased linamarin degradation during solid-substrate fermentation of cassava
}

\author{
A.J.A. Essers, ${ }^{*}$ M.H.J. Bennik and M.J.R. Nout
}

Several fungi and bacteria, isolated from Ugandan domestic fermented cassava, released HCN from linamarin in defined growth media. In $72 \mathrm{~h}$, a Bacillus sp. decreased the linamarin to $1 \%$ of initial concentrations, Mucor racemosus to $7 \%$, Rhizopus oryzae and $R$. stolonifer to $30 \%$, but Neurospora sitophila and Geotrichum candidum hardly degraded the linamarin. Adding pectolytic and cellulolytic enzymes, but not linamarase, to root pieces under aseptic conditions, led to root softening and significantly lower linamarin contents. Neurospora sitophila showed no linamarase activity, in contrast to $M$. racemosus and Bacillus sp., both of which were less effective in root softening and decreasing the root linamarin content. The most important contribution of microorganisms to linamarin decrease in the solid-substrate fermentation of cassava is their cell-wall-degrading activity, which enhances the contact between endogenous linamarase and linamarin.

Key words: Cassava, cell-wall-degrading enzymes, fungi, linamarin, Neurospora sitophila, solid-substrate fermentation.

The tropical starchy root crop cassava (Manihot esculenta Crantz) contains small amounts of cyanogenic glucosides, especially linamarin (Butler 1965). Disintegration of the tissue structure results in contact of linamarin with linamarase, which is located in the cell walls (Mkpong et al. 1990), and subsequent hydrolysis to glucose and cyanohydrins, which easily break down to ketones and $\mathrm{HCN}$ (Cooke 1978). To prevent toxicity, cassava roots with high cyanogen concentration are usually processed before consumption. Many processing methods have been developed by the cassava-farming population (Lancaster et al. 1982). One of these, which is used in several African countries and has been studied recently (Essers et al. 1995a) involves a 3- to 4-day solid-substrate fermentation in covered heaps after a short initial sun-drying. During incubation, a varied and abundant microflora develops; the roots become covered with a blanket of fungal mycelia and gradually soften from

\footnotetext{
A.J.A. Essers and M.H.J. Bennik were and M.J.R. Nout is with the Department of Food Science, Wageningen Agricultural University, Bomenweg 2,6703HD Wageningen, The Netherlands. A.J.A. Essers is now with the Department of Toxicology, Wageningen Agricultural University, PO Box 8000, 6700EA Wageningen. The Netherlands; tax: 31837084931 . M.H.J. Bennik is now with the Agrotechnological Research Institute, PO Box 17, 6700AA Wageningen, The Netherlands.

*Corresponding author.
}

the outside towards the centre. Subsequently, the mycelia are removed and the roots are crushed and submitted to final sun-drying before being pounded into flour. Incubation alone reduces linamarin contents but the microflora causes an additional effect, associated with root softening (Essers et al. 1995b). Two possible mechanisms contributing to this effect are introduction of microbial linamarase to the cassava, and cell wall-degrading enzymes that permit contact between the compartmentally separated linamarin and endogenous linamarase.

The aim of the present study was to clarify the mechanism(s) of the solid-substrate fermentation process that enhance breakdown of cyanogenic glucosides. The linamarase activity of several microbial strains was evaluated and the effects of enzymatically induced root softening and exogenous linamarase on the cyanogenic glucosides were compared.

\section{Materials and Methods}

Roots, Enzymes and Picrate Paper

Cassava roots from Costa Rica, protected by a wax layer, were obtained commercially in the Netherlands. Linamarase $(7.6 \mathrm{U} / \mathrm{ml})$ 
was extracted from fresh Ugandan roots according to Cooke (1979). One unit (U) was defined as the amount hydrolysing 1 $\mu \mathrm{mol}$ linamarin $/ \mathrm{min}$ at $30^{\circ} \mathrm{C}$ in $0.1 \mathrm{M}$ phosphate, $\mathrm{pH} 6.0$. Picrateimpregnated paper was made by immersing strips of filter paper in a solution of equal volumes of saturated picric acid and $5 \%$ (w/v) $\mathrm{Na}_{2} \mathrm{CO}_{3}$. Pectinex Ultra-sp (Novo Nordisk, Denmark) $(0.5 \%, w / v)$ was used for cell-wall degradation.

\section{Growth Media}

The yeasts and moulds, bacilli, and lactic acid bacteria were prem cultured on yeast nitrogen base (YNB; Difco) plus $1 \%(w / v)$ agar and $5 \%(\mathrm{w} / \mathrm{v})$ glucose, at $25^{\circ} \mathrm{C}$ for $48 \mathrm{~h}$, BHI broth (Gibco) at $30^{\circ} \mathrm{C}$ for $24 \mathrm{~h}$, and MRS agar (Merck) plus $1 \%(\mathrm{w} / \mathrm{v})$ agar at $30^{\circ} \mathrm{C}$ for $24 \mathrm{~h}$, respectively.

\section{Defined Growth Media for Testing Linamaruse Activity}

Linamarin-containing media with a low glucose content were used to screen linamarase activity. For yeasts and moulds, YNB plus $0.5 \%(\mathrm{w} / \mathrm{v})$ glucose, plus $1 \%(\mathrm{w} / \mathrm{v})$ agar and $0.01 \%(\mathrm{w} / \mathrm{v})$ linamarin (Sigma) in $0.1 \mathrm{M}$ sodium phosphate buffer, $\mathrm{pH} 6.15$, was used. For bacilli, $0.5 \%(\mathrm{w} / \mathrm{v})$ neutralized bacterial peptone (Oxoid) plus $0.2 \%$ ( $w / v$ ) Lablemco meat extract (Oxoid), $0.1 \%(w / v)$ Tween 80 (Merck), $0.02 \%$ (w/v) $\mathrm{MgSO}_{4}, 7 \mathrm{H}_{2} \mathrm{O}, 0.0056 \%$ (w/v) $\mathrm{MnSO}_{4}, \mathrm{H}_{2} \mathrm{O}$. $0.5 \%(\mathrm{w} / \mathrm{v})$ glucose, $1.0 \%(\mathrm{w} / \mathrm{v})$ agar and $0.01 \%(\mathrm{w} / \mathrm{v})$ linamarin (Sigma) in $0.1 \mathrm{M}$ sodium phosphate buffer, $\mathrm{pH} 6.0$, was used. For lactic acid bacteria, the medium for bacilli was used, without agar. For quantification of linamarase activity, the same media were used without agar.

\section{Screening Microorganisms for Linamarase Capacity}

The breakdown of linamarin and subsequent volatilization of $\mathrm{HCN}$ were examined with picrate-impregnated paper, fixed in the headspace of test tubes. Microorganisms, isolated from Ugandan, domestic, solid-substrate fermented cassava, described in Essers of al. (1995a), were inoculated on the relevant medium. After 4 days at $25^{\circ} \mathrm{C}$ (yeasts and moulds) or $30^{\circ} \mathrm{C}$ (bacilli and lactobacilli), the colour of the picrate-impregnated papers was compared with a standard range.

\section{Linamarase Activity of the Dominant Microorganisms}

Five 250-ml Erlenmeyer flasks, each containing $20 \mathrm{ml}$ of the corresponding linamarin-containing medium, were inoculated with Rhizopus oryzae, Mucor racemosus, Neurospora sitophila, Geotrichum candidum or a Bacillus sp. (one species/flask). A control was left uninoculated. A strip of picrate-impregnated paper was fixed in the headspace as a qualitative indicator of $\mathrm{HCN}$. After $72 \mathrm{~h}$ at $26^{\circ} \mathrm{C}$, residual cyanogens and mycelial weight were assayed. The incubation time and temperature are similar to the conditions observed in domestic processing in rural Uganda. The experiment was performed in quadruplicate.

Enzyme-induced Cassava Structure Loss and Linamarin Degradation The effect of tissue-structure loss on linamarin breakdown was examined by incubation of submerged cassava root pieces with a cell-wall-degrading enzyme complex, with and without additional linamarase, under aseptic conditions.

Preliminary testing of several commercial enzyme preparations indicated that the cellulolytic and pectolytic activity of Pectinex Ultra-sp was able to soften cassava root tissue. Linamarase activity, measured according to the procedure of Cooke (1979), was absent from this preparation. To determine if the proteolytic capacity of Pectinex Ultra-sp (Tableros et al. 1987) would affect linamarase activity, the activity of succinate buffer $(0.05 \mathrm{M}, \mathrm{pH} 5.5)$ initially containing $0.26 \mathrm{U}$ linamarase $/ \mathrm{ml}$, with and without addition of
$0.5 \%(w / v)$ Ultra-sp, was measured according to Cooke (1979) after 0,4 and $23 \mathrm{~h}$. No interference of Pectinex Ultra-sp with linamarase was found. The $0.04 \%(w / v)$ sodium azide used as preservative had no interference on the cyanogen assay.

A cassava root was peeled aseptically and cut into two pieces. These pieces were immersed for $30 \mathrm{~min}$ in $70 \%(\mathrm{v} / \mathrm{v})$ ethanol, then $1 \mathrm{~min}$ in sterile water, and, after discarding the $0.5 \mathrm{~cm}$ diam. central column, diced aseptically into cubes of about $1 \mathrm{~cm}^{3}$. Five batches of disinfected cubes (approx. $11 \mathrm{~g}$ ) were transferred to 30$\mathrm{ml}$ sterile cups and submerged under $15 \mathrm{ml}$ succinate buffer $(0.05 \mathrm{M}$, $\mathrm{pH} 5.5)$ containing $0.02 \%(\mathrm{w} / \mathrm{v})$ sodium azide to prevent microbial activity. One cup was assayed immediately (control); the remaining four received no addition, $0.5 \%(\mathrm{w} / \mathrm{v})$ Pectinex Ultra-sp, crude linamarase $(0.26 \mathrm{U} / \mathrm{ml})$, or $0.5 \%$ ( $\mathrm{w} / \mathrm{v})$ Pectinex Ultra-sp and crude linamarase $(0.26 \mathrm{U} / \mathrm{ml})$. The amount of linamarase used approximates to the average linamarase activity in $11 \mathrm{~g}$ fresh root. according to De Bruijn (1973). After incubation for $16 \mathrm{~h}$ at $40^{\circ} \mathrm{C}$. cyanogens and microbial counts were determined. The experiment was performed in quadruplicate.

\section{Analyses}

Semi-quantitative determination of $\mathrm{HCN}$ release was by picrateimpregnated paper. This method was derived from the leaf-picrate test (Sadik et al. 1974) and is based on the change of picrate from yellow to brown-red after contact with HCN (Guignard 1906). Tubes, containing standards of 0 to $100 \mathrm{mg}$ linamarin $/ 1$ phosphate buffer $(0.1 \mathrm{M}, \mathrm{pH} 6.0)$, to which $1 \mathrm{U}$ linamarase was added, were fitted with picrate-impregnated filter paper in the headspace and incubated for $24 \mathrm{~h}$ at $30^{\circ} \mathrm{C}$. This resulted in six pieces of coloured paper with increasing redness and these were photographed to give a semi-quantitative reference scale.

Cyanogens were extracted and assayed according to Essers et al. (1993). In the experiment on enzyme-induced linamarin degradation, each sample of $11 \mathrm{~g}$ cassava pieces with $15 \mathrm{ml}$ soak solution was homogenized in $44 \mathrm{ml} 0.1 \mathrm{M} \mathrm{H}_{3} \mathrm{PO}_{4}$. Moisture in fresh cassava was determined in quadruplicate by oven-drying at $105^{\circ} \mathrm{C}$ to constant weight. Total counts of mesophilic aerobic microorganisms were carried out by surface plating on plate count agar (Oxoid) and incubating at $30^{\circ} \mathrm{C}$ for 3 days. The dry weight of mycelial biomass was assayed by filtering the culture broth

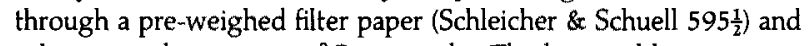
subsequent drying at $100^{\circ} \mathrm{C}$ overnight. The bacterial biomass was determined in the same way after centrifugation for $10 \mathrm{~min}$ at $2000 \times \mathrm{g}$. Root softening was considered complete when a $3 \mathrm{~mm}$ diam. glass rod could be pushed through a $1-\mathrm{cm}$ thick root piece without noticeable hindrance.

\section{Stalistical Analyses}

Treatment effects were compared by the Protected Least Significant Difference method (PSD) (Snedecor \& Cochran 1980). Significance of differences is presented as two-tailed probability $(P)$ values.

\section{Results and Discussion}

Mucor and Rhizopus sp. were able to release HCN from linamarin but Geotrichum candidum, Aspergillus, Neurospora, Penicillium and Scopulariopsis sp. were unable to do so. Most of the yeasts and lactobacilli released HCN, and two of the four bacilli released a small amount of $\mathrm{HCN}$ (Table 1).

Quantification of linamarin breakdown by microorgan- 
Table 1. HCN release from a linamarln-containing, defined growth medlum after 4 days' incubation with isolates of microorganisms from Ugandan, on-farm fermented cassava.

Organism

No. of isolates showing:

$\begin{array}{ccc}\text { No } & \text { Moderate } & \text { Strong } \\ \text { release } & \text { release } & \begin{array}{r}\text { release } \\ \text { rele }\end{array}\end{array}$

\begin{tabular}{|c|c|c|c|}
\hline Aspergillus fumigatus & 1 & & \\
\hline Aspergillus niger & 1 & & \\
\hline Aspergillus oryzae & 1 & & \\
\hline Aspergillus parasiticus & 5 & & \\
\hline Fusarium sporotrichoides & 1 & & \\
\hline Geotrichum candidum & 11 & & \\
\hline Mucor circinelloides & & & 2 \\
\hline Mucor racemosus & & & 10 \\
\hline Neurospora crassa & 1 & & \\
\hline Neurospora sitophila & 9 & & \\
\hline Penicillium frequentas & 1 & & \\
\hline Penicillium funicolosum & 1 & & \\
\hline Penicillium grisofulvum & 1 & & \\
\hline Penicillium rugulosum & 1 & & \\
\hline Penicillium waksmanii & 1 & & \\
\hline Rhizopus oryzae & & 1 & \\
\hline Rhizopus stolonifer & & 7 & \\
\hline Scopulariopsis brevicaulis & 1 & & \\
\hline Scopulariopsis fuxa & 1 & & \\
\hline Lactobacillus spp. & 5 & 12 & 3 \\
\hline Bacillus spp. & 2 & 2 & \\
\hline Yeasts & 2 & 10 & 2 \\
\hline
\end{tabular}

isms (Figure 1) showed that Neurospora sitophila and Geotrichum candidum did not hydrolyse appreciable amounts of linamarin but Bacillus sp. hydrolysed virtually all. Mucor racemosus hydrolysed at least $90 \%$ of the linamarin and Rhizopus oryzae $45 \%$ to $84 \%$. Although R. stolonifer was not included in this experiment, earlier experiments showed similar linamarin breakdown by $R$. oryzae and $R$. stolonifer under the same conditions. The picrate-impregnated paper indicated $\mathrm{HCN}$ escape from the media cultured with Mucor, Rhizopus and Bacillus but not from the ones with Geotrichum or Neurospora.

The findings of the quantitative experiment were consistent with the findings from the screening, except for Bacillus sp. The HCN release by the Bacillus sp. was lower than one would expect from the residual linamarin measured. A possible explanation for this is that the Bacillus sp. assimilated part of the HCN. It is known that several microorganisms are capable of metabolizing $\mathrm{HCN}$ (Knowles \& Bunch 1986). Padmaja \& Balagopal (1985) described linamarase and rhodanese activity, as well as cyanide assimilation, by Rhizopus oryzae isolated from rotting cassava. Rhodanese can form thiocyanate $\left(\mathrm{SCN}^{-}\right)$from $\mathrm{CN}^{-}$if suitable sulphur sources are available. The thiocyanate formed may then be used for mycelium formation but, if accumulated, would be assayed as non-glucosidic cyanogen.
Although Neurospora sitophila is known to be a producer of $\beta$-glucosidase (Oguntimein \& Moo-Young 1991), the strain tested did not break down significant amounts of the linamarin under the prevailing conditions. $\beta$-Glucosidases are substrate specific and therefore not all can degrade linamarin. The $\mathrm{pH}$ of the medium after incubation remained between 5.0 and 6.3, which is adequate for linamarase activity from various sources (Cooke et al. 1978; Okafor \& Ejiofor 1985).

The mean ( \pm standard deviation) fungal biomass developed in $72 \mathrm{~h}$ was $171 \pm 21 \mathrm{mg}$ and was the same order for all fungi, while the bacillus biomass was $475 \pm 205 \mathrm{mg}$. Although biomass development and enzyme excretion do not necessarily coincide, the results indicate that the superior linamarase activity exhibited by Mucor cannot be attributed to the growth conditions being specifically favourable for this fungus, nor to its higher biomass.

From earlier experiments (Essers et al. 1995b), we know that Neurospora sitophila was best at reducing linamarin in fermenting cassava, followed by Rhizopus sp. Bacillus sp., Geotrichum candidum and Mucor racemosus were less effective and also caused less root softening than the Neurospora and Rhizopus sp. In the present experiments, N. sitophila showed no linamarase activity, and there is no indication that this would be different in cassava. This indicates that the structure loss, caused by the enzyme system of $N$. sitophila, is of greater importance for linamarin degradation than the combination of low cell-wall-degrading and high linamarase activity of $M$. racemosus and the Bacillus sp. Comparing N. sitophila and $R$. oryzae, the latter proved at least as effective in softening cassava root tissue (Essers et al. 1995b) and displayed linamarase activity (present study) but was less effective in diminishing linamarin levels in cassava (Essers et al. 1995b). Therefore, it seems that the type of cell-wall degradation produced by $N$. sitophila is better suited to enable endogenous linamarase-linamarin contact.

In the experiment on enzyme-induced linamarin degradation, microbial counts in root pieces were $<10^{3} / g$ in all batches. This excludes interference from microbial contamination. The cassava pieces treated with Pectinex Ultra-sp or Ultra-sp plus linamarase were completely soft after $16 \mathrm{~h}$. Cassava root softening is caused by cell-wall degradation through the combined activity of pectinases and cellulases (Okolie \& Ugochukwu 1988). The residual cyanogen concentrations after the treatments are given in Table 2. Treatment with Pectinex Ultra-sp alone resulted in the lowest linamarin concentrations, both in the absolute sense, as well as relative to total cyanogen concentrations. These concentrations were significantly lower $(P<0.05)$ than those after other treatments. Second in terms of effectiveness was the combination of Pectinex Ultra-sp and linamarase. This also resulted in absolute and relative linamarin concentrations that were significantly lower $(P<0.05)$ 
Table 2. Cyanogens in cassava pleces before and after incubation with enzyme supplements.

\begin{tabular}{|c|c|c|c|c|}
\hline Enzyme added & $\begin{array}{l}\text { Incubation } \\
\text { (h) }\end{array}$ & $\begin{array}{c}\text { Total cyanogens * } \\
\text { (mg CN } \\
\text { equivalent/ } \\
\text { kg dry wt) }\end{array}$ & $\begin{array}{c}\text { Cyanogenic } \\
\text { glucosides *† } \\
\text { (mg CN } \\
\text { equivalent/ } \\
\text { kg dry wt) }\end{array}$ & $\begin{array}{c}\text { Ratio } t \\
\text { (Cyanogenic- } \\
\text { glucosides: cyanogens) }\end{array}$ \\
\hline None & 0 & $118 \pm 12$ & $112 \pm 14^{a}$ & $0.95^{\mathrm{a}}$ \\
\hline None & 16 & $131 \pm 8$ & $64 \pm 3^{0}$ & $0.49^{b}$ \\
\hline Pectinex Ultra-sp $(0.68 \mathrm{mg} / \mathrm{g})$ & 16 & $93 \pm 4$ & $12 \pm 5^{c}$ & $0.13^{c}$ \\
\hline Linamarase $(0.36 \mathrm{U} / \mathrm{g})$ & 16 & $123 \pm 10$ & $59 \pm 4^{0}$ & $0.48^{\circ}$ \\
\hline $\begin{array}{l}\text { Pectinex Ultra-sp }(0.68 \mathrm{mg} / \mathrm{g}) \\
\text { linamarase }(0.36 \mathrm{U} / \mathrm{g})\end{array}$ & 16 & $107 \pm 6$ & $28 \pm 3^{d}$ & $0.26^{d}$ \\
\hline
\end{tabular}

* Values are means \pm standard deviations for four sets of replicates.

† Within-columns, values with different superscript letters differ significantly $(P<0.05)$.

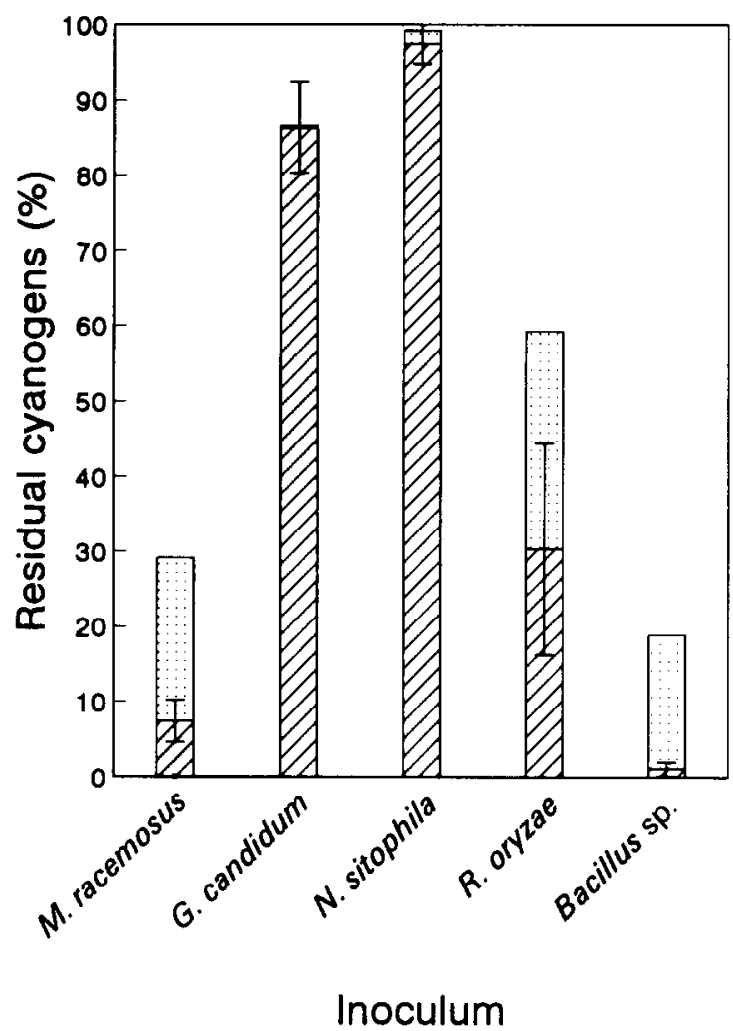

Figure 1. Mean $(N=4)$ residual cyanogen levels, as $\%$ of initial linamarin concentration, in defined growth media after $72 \mathrm{~h}$ at $26^{\circ} \mathrm{C}$. Error bars (standard deviations) are given for linamarin concentrations. $\square-$ Non-glucosidic cyanogens; linamarin.

than those in the other treatments. The concentrations after treatment with linamarase alone were not significantly different from those in the incubated controls.

Facilitating the contact between the substrate and the endogenous linamarase, through cell-wall degradation by Pectinex Ultra-sp, thus proved more effective in reducing the linamarin concentration than supplementing with linamarase. This is due to the inability of the exogenous linamarase to enter intact cassava cells and come in contact with its substrate. Once the cells are disrupted, additional linamarase may accelerate the linamarin breakdown, as was shown by Ikediobi \& Onyike (1982). The treatment with both linamarase and Pectinex Ultra-sp was therefore expected to be more effective than Pectinex Ultra-sp alone, but it was not. The reason for this is not clear.

The higher efficacy achieved by adding exogenous cellwall-degrading enzymes than by adding exogenous linamarase to intact cassava tissue was in line with the finding that a root-softening, but linamarase-deficient fungus ( $N$. sitophila) could be more effective in diminishing linamarin content than microorganisms displaying linamarase activity.

Overall, the results of the present study indicate that the main contribution of the microflora to the reduction of linamarin concentrations in solid-substrate fermentations of cassava is their cell-wall-degrading activity, which allows contact between endogenous linamarase and the linamarin. Their linamarase capacity is of lesser importance.

\section{Acknowledgements}

We thank M. Bosveld for the quantification of microbial linamarase activity. This study was financed by the Netherlands' Minister for Development Co-operation.

\section{References}

Butler, G.W. 1965 The distribution of the cyanoglucosides linamarin and lotaustralin in higher plants. Phytochemistry 4, 127-131.

Cooke, R.D. 1978 An enzymatic assay for the total cyanide content of cassava (Manihot esculenta Crantz). Joumal of the Science of Food and Agriculture 29, 345-352.

Cooke, R.D. 1979 Enzymatic assay for determining the cyanide content of cassava and cassava products. In CLAT Series $05 E C$, eds Ekelbaum, T. \& Gómes, G. pp. 3-14. Bogota: CIAT.

Cooke, R.D., Blake, G.G. \& Battershill, J.M. 1978 Purification of cassava linamarase. Phytochemistry 17, 381-383.

De Bruijn, G.H. 1973 The cyanogenic character of cassava (Mani- 
hot esculenta). In Chronic Cassava Toxicity: Proceedings of an Interdisciplinary Workshop, London, England, eds Nestel, B. \& MacIntyre, R. pp. 43-48. Ottawa: International Development Research Centre.

Essers, A.J.A., Bosveld, M., Van Der Grift, R.M. \& Voragen, A.G.J. 1993 Studies on the quantification of specific cyanogens in cassava products and introduction of a new chromogen. Journal of the Science of Food and Agriculture 63, 287-296.

Essers, A.J.A., Ebong, C., Van Der Grift, R.M. Otim-Nape, W., Nout, M.J.R. \& Rosling, H. 1995a Reducing cassava toxicity by heap-fermentation in Uganda. International Journal of Food Sciences and Nulrition 45, in press.

Essers, A.J.A., Jurgens, C.M.G.A. \& Nout, M.J.R. 1995b Contribution of selected fungi to the reduction of cyanogen levels during solid substrate fermentation of cassava. International Journal of Food Microbiology 24, in press.

Guignard, M.L. 1906 Chemie végétale - le haricot a acide cyanohydrique, Phaseolus lunatus L. Comptes Rendus Hebdomadaire des Seances de l'Academie des Sciences 142, 545-553.

Ikediobi, C.O. \& Onyike, E. 1982 The use of linamarase in gari production. Process Biochemistry 17, 2-5.

Knowles, C.J. \& Bunch, W. 1986 Microbial cyanide metabolism. Adoances in Microbiology and Physiology 27, 73-111.

Lancaster, P.A., Ingram, J.S., Lim, M.Y. \& Coursey, D.G. 1982 Traditional cassava based foods: survey of processing techniques. Economic Botany 36, 12-45.

Mkpong, O., Hua-Yan, E., Chism, G. \& Sayre, R.T. 1990 Purifi- cation, characterization and location of linamarase in cassava. Planl Physiology 93, 176-181.

Oguntimein, G. \& Moo-Young, M. 1991 Production and properties of $\beta$-glucosidases by Neurospora sitophila. World lournal of Microbiology and Biotechnology 7, 4-11.

Okafor, N. \& Ejiofor, M.A.N. 1985 The linamarase of Leuconostoc mesenteroides. Journal of the Science of Food and Agriculture 36, 669-276.

Okolie, N.P. \& Ugochukwu, E.N. 1988 Changes in activities of cell-wall-degrading enzymes during fermentation of cassava (Manihot esculenta Crantz) with Citrobacter freundii. Journal of the Science of Food and Agriculture 44, 51-61.

Padmaja, G. \& Balagopal, C. 1985 Cyanide degradation by Rhizopus oryzae. Canadian lournal of Microbiology 31, 663-669.

Sadik, S., Okerere, O.U. \& Hahn, S.K. 1974 Screening for Acyanogenesis in Cassava. Ibadan, Nigeria: IITA.

Snedecor, G.W. \& Cochran, W.G. 1980 Statistical Methods, 7th edn. lowa State University.

Tableros, M.A., Endress, H.U., Bannert, E., Finger, C., Shen, Z. \& Gierschner, K. 1987 Bestimmung verschiedener glycosidischer aktivitäten in enzympräparaten des handels. Industrielle Obstund Gemüseverwertung 72, 351-355.

(Received in revised form 16 November 1994; accepted 21 November 1994) 